\title{
Impact of Interest and Financing Expenses on Net Income from PT. BFI Finance Indonesia, Listing on the Indonesian Stock Exchange
}

\author{
Nurlaela \\ University Muslim of Maros, South of Sulawesi, Indonesia
}

\begin{abstract}
This study aims to examine the Effect of Interest and Financing Charges on Net Income at PT.BFI Finance Indonesia, Tbk. Listed on the Indonesia Stock Exchange. The type of data used is qualitative data and quantitative data and the source of the data used in this study is secondary data sourced from the financial statements of PT.BFI Finance Indonesia, Tbk. listed on the Indonesia Stock Exchange. The analytical method used is simple linear regression analysis, correlation coefficient, coefficient of determination and $T$ test. The results of this study are interest and financing charges have no significant effect on net income at PT. BFI Finance Indonesia Tbk which is listed on the Indonesia Stock Exchange.
\end{abstract}

Keywords: Interest and financing charges, Net income

\section{Introduction}

There are several factors that affect the survival and smooth running of a company's activities. In general, companies always try to increase net income. The thing that affects the achievement of maximum profit is the use of managed costs by the company, be it income or expenses, one of the expenses that contributes to the acquisition of net income, namely expenses and finance (Interest and financing charges). Good management must be able to control its business activities, one of which is to carry out efficiency in the expenses incurred during business activities. If the company can reduce costs and expenses, the company will be able to increase net income. Likewise, vice versa, if there is a waste of costs and expenses it will result in a decrease in profit.

Things like this are what open opportunities for financial institutions, both Non-Bank Financial Institutions and Bank Financial Institutions. Business and to meet the urgent needs of someone. And these financial institutions can get funds easily and quickly without requiring a long process or long procedure. One of them is at PT. BFI Finance Indonesia, Tbk.

PT. BFI Finance Indonesia, Tbk is a finance company or institution engaged in finance or financing. PT. BFI Finance Indonesia, Tbk is one of the largest finance companies in Indonesia in terms of assets and operational network, with the support of more than 340 outlets throughout Indonesia and more than 9000 employees. The company focuses its business activities on automotive and non-automotive financing, which consists of financing for four-wheeled vehicles, financing vehicles for vehicle collateral, as well as leasing for heavy equipment, machinery and others.

PT.BFI Finance Indonesia, Tbk is a non-bank financial company with the main activity of the company is to run a financing business in the form of providing funds or capital goods in the form of finance leases and consumer financing. The scope includes investment financing, working capital financing, multipurpose financing and other business activities based on the approval of the Financial Services Authority.

Based on the description of the background and identification of the research problems above, the authors formulate the problem: "Do Interest and Financing Charges affect Net Income at PT. BFI Finance Indonesia, Tbk. Listed on the Indonesia Stock Exchange?"

\section{Materials and Methods}

\subsection{Time and Location Research}

This will be conducted from 2015 until 2019. The research location iscapital market information center as representative of the Indonesian stock exchange, which is located in Makassar, South of Sulawesi.

\subsection{Sources of Data}

The data used in this study is secondary data obtained from the Indonesia Stock Exchange in the form of financial reports from 2015 to 2019.

\subsection{Data Collection Technique}

Data collection techniques in this study are to use documentation techniques, where the documentation taken is in the form of company financial report data for 2015 to 2019.

\subsection{Analysis}

To find an interest and financing charge ( $\mathrm{x}$ value) against net income (y value) and to prove the hypothesis, the analytical methods used are: 


\section{a) Simple Linear Regression}

This analysis aims to see the effect or relationship between the independent variable (net income) on the dependent variable (Interest and financing charges). Researchers use the SPSS version 22 for windows application.

The model used in this study is a simple regression equation with the following formula:

Information:

$$
\mathrm{Y}=\mathrm{a}+\mathrm{bX}
$$

$\mathrm{Y}=$ Independent variable (net income)

$\mathrm{a}=$ Constant

$\mathrm{X}=$ dependent variable (Interest and financing charges)

$\mathrm{b}=$ independent variable regression coefficient

\section{b) Coefficient of Correlation}

According to Sugiyono (2010: 228), the correlation coefficient is used to analyze if the researcher intends to know the effect or relationship between the independent and dependent variables by using SPSS version 22 for windows data processing, where one of the independent variables is made fixed or controlled.

Table 1. Guidelines for Providing Interpretation of Correlation Analysis

\begin{tabular}{|c|c|}
\hline Coefficient interval & Relationship level \\
\hline $0,00-0,199$ & Very weak \\
\hline $0,20-0,399$ & Weak \\
\hline $0,40-0,559$ & Moderate \\
\hline $0,60-0,799$ & Strong \\
\hline $0,80-1,000$ & Very strong \\
\hline
\end{tabular}

Source: Sugiyono (2015: 231)

\section{c) Coefficient of Determination}

The coefficient of determination is a way to measure how much the model's ability to explain the variation in the dependent variable. The value of the coefficient of determination is between 0 and 1 . The small $\mathrm{KD}$ value means that the ability of the independent variable to explain the variation of the dependent variable is very limited, using SPSS version 22 for windows data processing to determine how much influence the independent variables (Interest and financing charges) have on dependent variable (Net income).

A value close to one means that the independent variable provides almost all the information needed to predict the variation in the dependent variable (Ghozali, 2013: 95).

\section{d) Hypothesis Testing}

According to Ghozali (2013: 97) states that: "The t statistical test basically shows how far the influence of one independent / explanatory variable individually in explaining the variation of the dependent variable". This $t$ test is used to test the regression coefficient partially from the independent variable to the dependent variable, namely to see the influence of the variable. To measure the hypothesis test, the researcher uses the SPSS version 22 for windows application.

The $\mathrm{t}$ test is done by comparing t-count with t-table at a significant level of $5 \%$ with $\mathrm{dk}=\mathrm{n}-1$. Based on the formulation of the problem and hypothesis or temporarily, the hypothesis is tested with the following conditions:

If T-count> T-table then the Hypothesis is accepted.

If $\mathrm{T}$-count < $\mathrm{T}$-table then the Hypothesis is rejected.

\section{Results and Discussion}

\section{a) Simple Linear Regression}

To calculate the effect of the independent variable (Interest and financing charges) on the dependent variable (Net income). By using SPSS version 22 for windows as follows:

Table 2: The results of the calculation of regression analysis of Interest and financing charges on net income at PT. BFI

Finance Indonesia Tbk which is listed on the Indonesian stock exchange

\begin{tabular}{|c|c|c|c|c|c|c|}
\hline \multicolumn{7}{|c|}{ Coefficients $^{\mathrm{a}}$} \\
\hline & \multirow[b]{2}{*}{ Model } & \multicolumn{2}{|c|}{$\begin{array}{l}\text { Unstandardized } \\
\text { Coefficients }\end{array}$} & \multirow{2}{*}{$\begin{array}{c}\text { Standardized } \\
\text { Coefficients } \\
\text { Beta } \\
\end{array}$} & \multirow[b]{2}{*}{$\mathrm{T}$} & \multirow[b]{2}{*}{ Sig. } \\
\hline & & B & \begin{tabular}{|l|} 
Std. \\
Error \\
\end{tabular} & & & \\
\hline 1 & (Constant) & $\begin{array}{c}- \\
40035539 \\
4,901\end{array}$ & $\begin{array}{l}1049852 \\
325,911\end{array}$ & &,- 381 & ,728 \\
\hline & $\begin{array}{c}\text { Interest and } \\
\text { Financing } \\
\text { changes }\end{array}$ & 1,534 & 1,170 & ,604 & 1,311 & ,281 \\
\hline
\end{tabular}

a. Dependent Variable: Net Income

$Y=-\mathbf{4 0 0 3 5 5 3 9 4 . 9 0 1 + 1 . 5 3 4 X}$

Information:

$\mathrm{Y}=$ Net Income

$\mathrm{X}=$ Interest and financing charges

These numbers can be interpreted as follows:

a) The constant value obtained is -400355394.901 , meaning that if the Interest and financing charges $(\mathrm{X})$ are 0 , then the Net income (Y) is negative, namely -400355394.901.

b) The variable regression coefficient for Interest and financing charges is 1.534 , meaning that if Interest and financing charges increase by Rp. 1, then the Net Income earned will increase by Rp. 1 .

\section{b) Coefficient of Correlation}

Table 3: Results of Interest and Financing Change Correlation Coefficient Calculation Against Net Income at PT. BFI Financing Indonesia Tbk Listed on the Indonesia Stock Exchange.

\begin{tabular}{|c|c|c|c|c|}
\hline \multicolumn{5}{|c|}{ Model Summary } \\
\hline Model & $\mathrm{R}$ & $\begin{array}{c}\mathrm{R} \\
\text { Square }\end{array}$ & $\begin{array}{c}\text { Adjusted R } \\
\text { Square }\end{array}$ & $\begin{array}{c}\text { Std. Error of the } \\
\text { Estimate }\end{array}$ \\
\hline 1 &, $604^{\mathrm{a}}$ &, 364 &, 152 & 323298752,794 \\
\hline \multicolumn{5}{|c|}{ a. Predictors: (Constant), Interest and Financing charges } \\
\hline
\end{tabular}

Based on the SPSS output table by analyzing the correlation coefficient, the value (r) of 0.604 is obtained, this means that the closeness of the relationship between interest and financing charges to net income is in a "strong" position because it is in the correlation coefficient interval value of $0,60-0,799$. 


\section{c) Coefficient of Determination}

Table 4.Calculation Results of the Determination Coefficient of Cash Flow against Liquidity Level at PT. BFI Finance Indonesia Tbk.

\begin{tabular}{|c|c|c|c|c|}
\hline \multicolumn{5}{|c|}{ Model Summary } \\
\hline Model & $\mathrm{R}$ & $\begin{array}{c}\mathrm{R} \\
\text { Square }\end{array}$ & $\begin{array}{c}\text { Adjusted R } \\
\text { Square }\end{array}$ & $\begin{array}{c}\text { Std. Error of the } \\
\text { Estimate }\end{array}$ \\
\hline 1 &, $604^{\mathrm{a}}$ &, 364 &, 152 & 323298752,794 \\
\hline \multicolumn{4}{|c|}{ a. Predictors: (Constant), Interest and Financing charges } \\
\hline
\end{tabular}

The value of R-square used to determine the influence of the independent variable on the dependent variable is 0.364 . This figure means $36.4 \%$. While the remaining $63.6 \%$ is influenced by other variables, this means that the close relationship of interest and financing charges to Net income is in a "low" position because it is in the determination coefficient interval value of $20 \%-39.9 \%$.

\section{d) Hypothesis Testing}

Based on the results of the spss in Table 2, the t-count with the Interest and financing charges variable on Net income is 1.311 and the t-table value is 2.353 , then the t-table value is $1.311<\mathrm{t}$-table 2.353, this means that the proposed hypothesis is rejected or Interest and financing charges does not have a significant effect on Net income at PT. BFI Finance Indonesia Tbk which is listed on the Indonesian stock exchange. The hypothesis is rejected because the significant amount of $\mathrm{t}$-count $<\mathrm{t}$-table is $0.281<\alpha=0.05$, which indicates that the interest and financing charges variable has little influence on the net income variable. So that the hypothesis is rejected.

\section{Conclusion}

1) Interest and financing charges do not have a significant effect on Net income at PT. BFI Finance Indonesia, Tbk.

2) The hypothesis which states that Interest and financing charges do not have a significant effect on Net income at PT. BFI Finance Indonesia, Tbk. Not proven or rejected

\section{References}

[1] AgusMulyono. 2008. The Effect of Financing Chargers on Net Income at ADIRA Finance Kediri. http://academia.edu.com/index.php/jltr/article/view/jltr 6531458, Accessed on December 4, 2019.

[2] Andri. 2012. The effect of interest and financing charges on firm value. Journal of Management Imu Volume 1 Number 1 January 2012.

[3] BambangRiyanto. 2010. Burden and Cost of Case Studies of DPU and SETDA in Bantul Regency. Journal of Business and Management Studies.Volume 4 Number. 2. Pages 41-48.

[4] Ghozali, Imam. 2013. Application of Multivariate Analysis with the IBM SPSS 21 Update PLS Regression Program. Semarang: Dipenogoro University Publishing Agency.

[5] Hanafi and Abdul Halim. 2007. Effect of Capital Structure, Profitability and Firm Expenses on Firm Value.Udayana University Accounting E-Journal.
[6] Harahap. 2009. Cost management to net income at Mayoracompany. http://kpicenter.org/index. Accessed on 23 October 2019.

[7] Harianto and Sartono. 2012. Investment Management: Theory and Questions and Answers. Edition 2. Jakarta: Salemba.Empat.

[8] Indonesian Accountants Association. 2017. Statement of Financial Accounting Standards Number 69. Jakarta: Indonesian Institute of Accountants.

[9] Kasmir. 2012. Financial Statement Analysis. Jakarta: PT. Raja GrafindoPersada.

[10] Leon G. Schiffman and Leslie Lazar Kanuk. 2011. Consumer Behavior. Seventh Edition. Jakarta: PT. Index.

[11] Mamduh M. Hanafi and Abdul Halim. 2007. Expense and Profit Margin at the Company. Volume 3.

[12] Munawir, S. 2010. Analysis of Financial Statements.Fourth Edition. Fifteenth Prints. Yogyakarta: Liberty.

[13] Novi Andriani. 2009. The Effect of Interest and Dividends on Changes in Net Income at Bank Mandiri. http://academia.edu.com/index.php/jltr/article/view/jltr 0304716721, Accessed December 4, 2019.

[14] RajaAndri. 2012. Interest and financing charges against Organizational Citizenship Behavior. http://kpicenter.org/index. Accessed on 23 October 2019.

[15] Sartono, Agus. 2012. Financial Management Theory and Applications. Edition 4. Yogyakarta: BPFE.

[16] Santoso, Singgih. 2012. SPSS Analysis on Parametric Statistics. Jakarta: PT Elex Media Komputindo.

[17] Sugiyono. 2013. Educational Research Methods (Quantitative Approaches, Qualitative, and R \& D). Bandung: Alfabeta.

[18] Warren et.al. 2015. Causes of Failure in the Company. Yogyakarta: BPFE. 